\title{
Assessing the benefits of sustainability certification of biofuels: how much are consumers willing to pay?
}

\author{
Azucena Gracia*, Jesús Barreiro-Hurlé*, Luis Pérez y Pérez*
}

\author{
DOI: $10.30682 / \mathrm{nm} 2002 \mathrm{a}$
}

JEL codes: D12, O13, Q41

\begin{abstract}
The European Union (EU) considers biofuels as an option to reduce GHG emissions. However, biofuels mandates are controversial because of the concerns regarding unintended environmental, social and economic consequences. EU renewable energy directives introduced some requirements that biofuels should meet to be certified as sustainable. Today almost all the EU's biofuel consumption intended for transport complies with the EU's sustainability requirements. This paper investigates social preferences in Spain for sustainable biofuels and, in particular, the willingness to pay (WTP) for sustainable biodiesel. To do that, a choice experiment approach was used with data from a survey conducted in Zaragoza. Results indicate that consumers are willing to pay, a premium of 5\% for biodiesel. This premium is slightly lower than the extra-price they are willing to pay for the convenience of finding biodiesel in their usual petrol station (6\%). We identified two segments of consumers according to their WTP for the different biodiesel characteristics. One segment was more willing to pay for biodiesel while the other one attached more importance to fuelling convenience and biodiesel availability.
\end{abstract}

Keywords: Biodiesel, Choice experiment, Preferences, Spain, Willingness to pay.

\section{Introduction}

Climate change is currently considered one of the most important threats that could have very serious impacts on growth and development (Stern, 2007; Nordhaus, 2010; World Bank, 2010; Niggol Seo, 2017; Tol, 2018). To avoid the risk of climate change, reducing greenhouse gases (GHG) emissions, particularly carbon dioxide, was suggested and countries have adopted energy saving and diversification strategies towards lower GHG energy sources. As transport is a major GHG emitting sector mainly due to fuel consumption in road traffic, and is the only sector where emissions have increased since 1990 (EEA, 2018a) many of these strategies included measures for the transport sector.

The EU is one of the cases where the transport sector was responsible of more than $20 \%$ of the total GHG emissions in 2010 and $27 \%$ in 2016 (EEA, 2012; 2018b). The former Renewable Energy Directive on the promotion of the use of energy from renewable resources (RED I) set a binding target of $20 \%$ final energy consumption from renewable sources by 2020 (EC, 2009 ) with a $10 \%$ share of renewable energy in transport. In December 2018, a revised Directive (RED II) entered into force as part of the legisla-

\footnotetext{
* Centro de Investigacion y Tecnologia Agroalimentaria de Aragon, Zaragoza, Spain.

Corresponding author: lperez@aragon.es
} 
tive package to allow the EU to comply with the 2015 Paris Accord on Climate Change, which includes a binding emission reduction target of at least $40 \%$ by 2030 with respect to 1990 values for the region (EU, 2018). RED II increased the binding renewable energy target for the EU for 2030 to at least $32 \%$, with a $14 \%$ share of renewable energy in transport. Both RED II \& I have included energy saving and diversification actions in transport due to the growing importance of greenhouse gas emissions in this sector.

Following intense controversies regarding the undesired effects of biofuels (mainly $1^{\text {st }}$ generation) on land use and food security, RED II limits the maximum contribution of biofuel produced from food crops for transport at $7 \%$ while setting binding targets for the incorporation of advanced biofuel, not derived from food crops (EU, 2018). Moreover, it requires biofuels to meet sustainability criteria related to use of land with high levels of biodiversity or high carbon levels and assures minimum carbon saving compared to fossil fuels. Meeting these criteria can be demonstrated by voluntary certification schemes. Besides the feedstock origin, both products are equivalent from a user perspective. Since the adoption of RED I biofuel consumption in the EU has risen from 11.5 to 15.5 Mtoe between 2009 and 2017, which implies an average growth rate of $3.7 \%$ in the period. With 1.3 Mtoe, Spain is today the fourth largest consumer of biofuel in the EU, after France, Germany and Sweden (EurObserv'ER, 2018).

In addition to the quantitative targets, the EU should assess the GHG performance, technical innovation and sustainability of fuels imports. Setting an obligation on Member States to require fuel suppliers to ensure a minimum share of advanced biofuels and certain biogases, is intended to encourage development of advanced fuels. Biofuels are promoted not only as an option to reduce GHG emissions but also as a way to increase energy security and to promote economic development in rural areas through increased activity levels and associated jobs. According to the European Environment Agency (EEA), total GHG emissions in the EU in 2016 reached 4,441 $\mathrm{MtCO}_{2}$, these emissions would have been $10 \%$ higher if the EU had not embraced renewable energy. The contribution from biofuels in transport to this reduction was $42 \mathrm{MtCO}_{2}$, or around $9 \%$ of total gross avoided emissions. The contribution of renewable energy to GHG mitigation is increasing and preliminary data for 2017 shows an increase of 6\% reaching nearly 500 Mtoe (EEA, 2018b). In 2018, the average GHG content of biofuels in Spain compared to fossil fuels was $20 \%$ above the European average and the minimum margins, between 50 and $36 \%$ to those required by European regulations (CNMC, 2019)

Transport model projections forecast that by 2030 internal combustion engines will be the main technology in road transport. A very small part $(0.5 \%)$ of total road transport will be covered by electricity (EC, 2016) and between 70 and $80 \%$ of the total light vehicle fleet will continue to run on combustion engines (CNMC, 2019), therefore biofuels will continue to be the only renewable option for a majority of transport vehicles. While in the long term (2050) a radical change in mobility is needed with biofuels being restricted to long-distance and heavy transport, at least up to 2030 they are clearly part of the technology mix to address the increased GHG emissions from transport (Tagliapietra et al., 2019).

As mentioned, biofuels mandates and targets have been on debate and under controversial discussions because on the increasing concerns of their unintended environmental, social and economic consequences associate with their production. Biofuels production could have strong impact on land use and agricultural markets, encouraging conversion of forested land to monoculture and increasing food prices (Banse et al., 2011; Britz \& Hertel, 2011; Scarlat \& Dallemand, 2011; Padella et al., 2012; Zhang et al., 2013; Farm Europe, 2016). As a response to these concerns RED II envisages support to the production of biofuels, bioliquids and biomass fuels when there is a low risk of indirect change in land use. With the aim of consuming a third of total final energy from renewable energies by 2030 , the maximum contribution of $1^{\text {st }}$ generation biofuels, biodiesel and bioethanol produced from food crops for transport is to be main- 
tained at $7 \%$, which is the same as the 2020 limit adopted in the Indirect Land Use Change (ILUC) directive (EU, 2015). In parallel, to boost the development of $2^{\text {nd }}$ generation biofuels, RED II has also set binding targets for the incorporation of advanced biofuel, not derived from food crops, with a minimum share of $0.2 \%$ in $2022,1 \%$ in 2025 and $3.5 \%$ by 2030 (EU, 2018)

As a way to prove that biofuels meet the sustainability criteria set by RED II the EU allows biofuel producers the use of a sustainable biofuel certification from a voluntary scheme that must be recognised by the EU. Once the EU recognizes a particular voluntary biofuel sustainability scheme, producers from both inside and outside the EU could certify their biofuel as sustainable. ${ }^{1}$

During RED I both certified and not certified biofuels co-existed in the market and it was feared that sustainability certification would add at least three costs to the production of biofuels: certification fees, internal adaptation to the certificate requirements and auditing fees that will be share along stakeholders in the supply chain although the final consumer will ultimately bear the costs of certified biofuels (Pancini \& Assunçao, 2011). However, these fears have been proved unwarranted and today the costs of certification are borne by the parties and most of the biofuel consumed in the EU certified as sustainable. Preliminary estimates suggest that today Member States-certified consumption would be slightly less than 15.5 Mtoe, which means that almost all the EU's biofuel consumption intended for transport now complies with the European Commission's sustainability requirements (EurObserv'ER, 2018). In this context, the aim of the paper is to study social preferences for biofuels and in particular, to assess how much consumers were willing to pay for sustainable biodiesel compared to its non-certified alternative. In addition, we try to assess whether price premiums declared by drivers were above certification costs when certified biodiesel was introduced.
Few empirical studies analysed the willingness to pay for biofuels (Table 1) since only in recent years, ethanol (mainly produced in the USA and Brazil), or biodiesel (mainly produced in the EU) have reached relevant production, and consumption figures (Lanzini et al., 2016). Following this geographical distribution of production and consumption, empirical papers conducted in USA focused on bioethanol, while papers conducted in Europe studied biofuels in general and biodiesel in particular. Two other papers study biodiesel and renewable fuel policy in Sri Lanka and South Korea, respectively (Sivashankar et al., 2016; Shin \& Hwang, 2017). Notwithstanding the diversity of results, the general conclusion for ethanol is that consumers are willing to pay a small premium, but this premium differs across different blending options. In particular, the willingness to pay (WTP) for the ethanol blending of $85 \%$ (E85) is higher than for the blending of $10 \%$ (E10). With respect to studies carried out in the EU it is interesting to highlight that all were carried out in southern countries. Two out of the four European papers study biofuels in general (Savvanidou et al., 2010; Lanzini et al., 2016) and both found a positive WTP for biofuels. The paper by Savvanidou et al. (2010) estimated a premium of 0.06 $€ / 1$ of biofuel and the one by Lanzini, a WTP between 0.07 and $0.14 € / 1$. The other two European papers analysed the WTP for biodiesel and were conducted in two northern Spanish regions finding premium for biodiesel between 0 and 0.05 $€ / 1$. Finally, Sivashankar et al. (2016) estimated an average WTP for biodiesel of $0.74 € / 1$ in Sri Lanka and Shin \& Hwang (2017) a WTP for renewable fuel standard policy between $0.33 \$ /$ gallon and 0.6 \$/gallon in South Korea.

Adding to the existing literature, our paper focus on a specific product, the $100 \%$ pure biodiesel (B100), takes into account its sustainability certification and it expands the analysis of drivers' preferences by investigating the possible preferences heterogeneity and profiling the different drivers' segments based on their willingness to

${ }^{1}$ As of July 2019 there are 16 approved certification programs (ec.europa.eu/energy/en/topics/renewable-energy/ biofuels/voluntary-schemes). 
Table 1 - Literature review on drivers' preferences for biofuels.

\begin{tabular}{|c|c|c|c|c|}
\hline Empirical papers & $\begin{array}{l}\text { Type of } \\
\text { biofuel }\end{array}$ & Country & $\begin{array}{l}\text { Valuation } \\
\text { Method }\end{array}$ & Findings \\
\hline Solomon \& Johnson, 2009 & Ethanol & USA & $\mathrm{CV}$ & $\begin{array}{l}\text { WTP of } 0.4 \$ \text { more per gallon of } \\
\text { gasoline. }\end{array}$ \\
\hline Giraldo et al., 2010 & Biodiesel & Spain & $\mathrm{CE}$ & $\begin{array}{l}\text { WTP of } 5 \% \text { over the price of } \\
\text { standard diesel. }\end{array}$ \\
\hline Jensen et al., 2010 & Ethanol & USA & $\mathrm{CE}$ & $\begin{array}{l}\text { Estimated mean WTP was } 0.136 \$ \text { / } \\
\text { gallon for E85 from corn, } 0.189 \$ \text { / } \\
\text { gallon for E85 from switchgrass, } \\
\text { and } 0.166 \$ \text { /gallon for E85 from } \\
\text { wood wastes. }\end{array}$ \\
\hline Petrolia et al., 2010 & Ethanol & USA & $\mathrm{CV}$ & $\begin{array}{l}\text { WTP between } 0.06-0.12 \text { \$/gallon } \\
\text { for E-10 \& 0.12-0.15 \$/gallon for } \\
\text { E-85. }\end{array}$ \\
\hline Savvanidou et al., 2010 & Biofuel & Greece & $\mathrm{CV}$ & WTP of $0.06 € / 1$ more for biofuel. \\
\hline Kallas \& Gil, 2014 & Biodiesel & Spain & $\mathrm{CE}, \mathrm{CV}$ & $\begin{array}{l}\text { Consumers are not willing to pay } \\
\text { for biodiesel. }\end{array}$ \\
\hline Aguilar et al., 2015 & Ethanol & USA & $\mathrm{CE}$ & $\begin{array}{l}\text { If the price of gasoline and ethanol } \\
\text { equals, E- } 85 \text { would dominate the } \\
\text { market. }\end{array}$ \\
\hline Lanzini et al., 2016 & Biofuel & Italy & $\mathrm{CV}$ & $\begin{array}{l}\text { Almost one fifth of respondents } \\
\text { declare their unwillingness to pay } \\
\text { a price premium for biofuels. } 29 \% \\
\text { are willing to pay a premium of up } \\
\text { to } 0.07 € / 1 \text {, while } 40 \% \text { are willing } \\
\text { to pay up to } 0.14 € / 1 \text {. Only a small } \\
\text { set of respondents ( } 13 \% \text { ) declares } \\
\text { higher WTP for biofuels (more than } \\
0.14 € / 1 \text { ). }\end{array}$ \\
\hline Sivashankar et al., 2016 & Biodiesel & Sri Lanka & $\mathrm{CV}$ & $\begin{array}{l}\text { The mean WTP for biodiesel was } \\
0.74 € / 1 \text {. }\end{array}$ \\
\hline Shin \& Hwang, 2017 & $\begin{array}{l}\text { Renewable } \\
\text { fuel }\end{array}$ & South Korea & $\mathrm{CE}$ & $\begin{array}{l}\text { WTP for renewable fuel standard } \\
\text { policy was between } 0.33 \$ \text { /gallon } \\
\text { and } 0.6 \$ \text { gallon. }\end{array}$ \\
\hline
\end{tabular}

$C V$ : Contingent valuation

$C E$ : Choice experiment

pay for biodiesel. The rest of the paper is structured as follows. After this introduction, Section 2 presents the materials, methods, section 3 the results, and Section 4 provides a summary of conclusions and the discussion.

\section{Material and methods}

Two valuation methods have been commonly used to measure willingness to pay for bio-based products, contingent valuation (Lanzini et al., 2016; Scarangelli et al., 2017) and discrete choice experiments (DCE) (Shin \& Hwang, 2017, Zemo \& Termansen, 2018). We apply the latter to measure drivers' willingness to pay for biodiesel because it allows the valuation of multiple attributes simultaneously, is consistent with the random utility theory, and the choice tasks asked to participants are similar to real choice decisions. 


\subsection{Theoretical background: choice experiment and heterogeneous preferences}

DCE is based on the Lancaster consumer theory of utility maximization (Lancaster, 1966) where that total utility depends on the product's characteristics. This utility is known to the individual but not to the researcher who observes some attributes but not others that can be treated as stochastic within the random utility model (McFadden, 1974). Then, utility is taken as a random variable where the utility from the $\mathrm{n}^{\text {th }}$ individual facing a choice among $j$ alternatives within choice set $J$ in each of $t$ choice occasions can be represented as,

$$
U_{n j t}=\beta^{\prime} x_{n j t}+\varepsilon_{n j t}
$$

Where $\beta$ is the vector of parameters, $x_{n j t}$ is the vector of attributes variables that are observed by the analyst in choice occasion $t$ and $\varepsilon_{n j t}$ is an unobserved random term that is distributed following an extreme value type I (Gumbel) distribution, i.i.d. over alternatives and independent of $\beta^{\prime} x_{n j}$.

Depending on the assumption about individual preferences, different models can be specified. In our case, we assume that individual' preferences are heterogeneous and a Random Parameters Logit (RPL) model considering a panel structure to take into account that several choices were made by each individual was used (Train, 2003). For this model, the parameters in the utility function are $\beta_{n}$ which deviates from the population mean $\beta$ by the deviation parameters $\eta_{n}$. Moreover, we assumed that the parameters $\beta_{n}$ are jointly distributed because some attributes may be inter-dependent. Therefore, the correlation structure of $\beta_{n}$ will follow a multivariate normal distribution (normal with vector mean $\mu$ and variance-covariance matrix $\Omega)$ (Scarpa \& Del Giudice, 2004).

From the estimated parameters $\left(\beta_{n}\right)$ the mean WTP for each attribute-level is calculated by taking the ratio of the mean estimated parameter for the non-monetary attribute to the mean price parameter multiplied by minus one. In addition, WTP estimates for each of the individuals were derived, by using the Bayes Theorem, from the expected value of the ratio between the non-monetary attribute and the price parameter (Scarpa et al., 2007).
To identify the sources of heterogeneity an expost analysis of the estimated WTPs for each of the respondents was used. In particular, a cluster k-means procedure using these estimated WTP as segmentation variables was conducted. The obtained segments were characterized by consumer's socio-demographic and economic characteristics, concerns on climate change, believes on the effects of biodiesel use and energy saving, knowledge on biodiesel, attitudes towards biodiesel, biodiesel use and environmental lifestyles. This characterization was done using a chi-square or Bonferroni test, depending on the nature of the variables (Hair et al., 1998). The cluster analysis, the ANOVA and chi-square tests were performed using STATA 14. Software (https://www.stata.com/).

\subsection{Survey and questionnaire design}

The results reported are based on primary data collected by means of a survey conducted in Zaragoza, a medium-sized town in Spain during 2010 and target population was adults using a motor engine vehicle (drivers). At the time of the survey certified biofuels were just being debated (i.e. none of the approved certification schemes mentioned in footnote 1 existed) thus we provide an ex-ante appraisal of their value to consumers. This town was selected because it is widely used by food marketers and market research consulting companies as the socio-demographics are representative of the Spanish Census of Population (Annex). The interviews were carried out face-to-face using a questionnaire.

The questionnaire was developed based on a previous study (Giraldo et al., 2010) and designed to identify attitudes, knowledge and preferences for different aspects of biodiesel in Spain. The questionnaire started with a screening question on whether interviewees were drivers of motor engine vehicles and then it was structured in four parts. The first part included some introductory questions about concerns on climate change and effects of biodiesel use and energy savings. In the second part, respondents were asked about their fuel purchase habits (where and why) and contained questions on knowledge, attitudes and actual and intended biodiesel consumption. Part 
Table 2 - Attributes and levels used in the choice design.

\begin{tabular}{|l|c|c|}
\hline \multicolumn{1}{|c|}{ Attributes } & Levels & Statu quo \\
\hline Price $(€ / \mathrm{l})$ & $1.05 ; 1.10 ; 1.15$ and 1.20 & 1.10 \\
\hline Type of diesel & $\begin{array}{c}\text { Biodiesel (BIO) } \\
\text { Biodiesel z certification } \\
\text { (BIOCERT) }\end{array}$ & Conventional Diesel \\
\hline Availability close to the everyday route & $\begin{array}{c}\text { Yes (AVAILABILITY) } \\
\text { No }\end{array}$ & Available in all petrol stations \\
\hline Place of production & $\begin{array}{c}\text { Europe (EUROPE) } \\
\text { Outside Europe }\end{array}$ & Outside Europe \\
\hline
\end{tabular}

three included the choice experiment tasks and, finally, part four gathered information on drivers' socio-demographic characteristics and environmental lifestyles.

The design of the choice experiment started with the selection of the attributes and levels to be used. The selected attributes should be relevant to the problem under analysis, realistic, believable and easy to understand by the average respondent (Bateman et al., 2002). To meet these requirements, results from Giraldo et al. (2010) and the pre-test of the current study were very relevant.

Two attributes were straightforward, price, because it allows the calculation of the willingness to pay, and the type of diesel, because it is the main objective of the paper. The third attribute, availability of the biodiesel in the petrol station close to their usual route, was selected as availability was highly valued by consumers in previous empirical papers conducted in Spain (Giraldo et al., 2010; Kallas \& Gil, 2014). Finally, the place of production of the diesel was selected because it is interesting to know to what extent consumers prefer the use of biodiesel produced in Europe.

For the price attribute, four levels were defined. The lowest level corresponds to the minimum price for diesel that was found in the Spanish market at the time of the survey (1.05 $€ / 1)$. The next level was set at the average price of diesel $(1.10 € / 1)$ and the other two levels at $1.15 € / 1$ and $1.20 € / 1$, respectively. For the type of diesel attribute, two levels were established: biodiesel and biodiesel with sustainable certificate. The third and the four attributes had also two levels. For the attribute availability, the two levels were: the diesel is available in a petrol station close to the individual's every day route or it is not available and drivers had to go to another petrol station. For the attribute place of production, the levels correspond to be produced in Europe or outside Europe. Table 2 shows the attributes and the levels used.

The choice set design was created following Street \& Burgess (2007). We started from a full factorial design with 32 profiles. The second option in the choice sets was then created using one of the generators deriving from the suggested difference vector $(1,1,1,1)$ by Street \& Burgess (2007), for 4 attributes with respectively 2 , 2, 2 and 4 levels, and two alternatives. Then, 80 choice sets were obtained with a D-efficiency of $97.8 \%$. To avoid fatigue effects associated with multiple choice tasks, respondents were asked to make six choices and the total number of choice sets were randomly split into different blocks.

Choice sets included three alternatives: two unlabeled alternatives of the different designed diesel options and the statu quo corresponding to conventional diesel, at the average price, available in all petrol stations and produced outside Europe. A description of the experiment was presented, indicating the selected attributes and levels for each of the diesel options.

The questionnaire was administrated to a stratified random sample of the population based on district, gender and age. For a sampling error of $\pm 5 \%$, a confidence level of $95.5 \%$ when estimating the proportion of individuals choosing one of the hypothetical options $(\mathrm{p}=\mathrm{q}=0.5 ; \mathrm{k}=2)$, the final sample size was set at 400 . Interviewers selected and approached individuals randomly, by making them a screening question on wheth- 
er or not they were drivers of a motor vehicle. In the case of a negative response, interviewers randomly selected another person belonging to a given age group, until they obtained a positive response.

Before the final questionnaire was administrated, a pilot survey was undertaken to identify consumer believes and knowledge with regards to biodiesel and to help selecting the most relevant diesel attributes to be included in the final choice experiment design. This pre-test survey was conducted to a small sample of respondents $(\mathrm{N}=20)$.

\subsection{Model specification and estimation}

The final specification of the utility function included the different attributes-levels in the following way:

$U_{n j t}=\beta_{n 1}$ PRICE $_{n j t}+\beta_{n 2}$ BIO $_{n j t}+\beta_{n 3}$ BIOCERT $_{n j t}$ $+\beta_{n 4}$ AVAILABILITY $_{n j t}+\beta_{n 5}$ EUROPE $_{n j t}+\varepsilon_{n 5}$

$\mathrm{w}$ here, $J$ indicates the three alternatives in the choice. The price variable represents the four price levels for the diesel $(1.05,1.10,1.15$ and $1.20 € / 1$, respectively). For the diesel attribute, two dummy variables were built (BIO and BIOCERT) where 1 indicates the corresponding type of diesel and 0, otherwise (Table 2). The availability of the biodiesel in a petrol station close to the everyday route (AVAILABILITY) is a dummy variable where 1 indicates that the biodiesel is available and 0 , otherwise. The place of production variable (EUROPE) is also a dummy variable where 1 denotes that the biodiesel is produced in Europe and 0, otherwise. It is expected that the price variable will have a negative impact on utility based on the economic theory and the rest of dummy variables are expected to have a positive effect. Different models were specified for the utility function to test whether preferences are homogeneous and estimated parameters $\beta_{n}$ are correlated. First, a Multinomial Logit (MNL) model was specified assuming drivers had homogenous preferences and second, an RPL model allowing preferences to be heterogeneous across drivers was defined (Train, 2003). Finally, an RPL model with correlated errors (RPL-corr) to take into account the possible correlation across parameters was also specified. For the RPL models, all the variables except for the price were allowed to be random following a normal distribution. For the estimation of the RPL models, we used 200 Halton draws rather than pseudo-random draws since the former provides more accurate simulations (Train, 2003). All estimations were conducted using NLOGIT 5.0 Econometric Software, Inc. (http://www.limdep.com/products/nlogit/).

\section{Results}

Summary statistics for the socio-demographic and economic characteristics of the sample are presented in Table 3.

This table includes also information on fuelling habits both in terms of frequency and fidelity to a specific petrol station. As far as the basic characterization of our sample is concerned, about half of respondents were female $(49 \%)$ with an average age of 44 years and living in households of 3 people. Around $30 \%$ of respondents stated that their household monthly net income was between 1,500 $€$ and 2,500 $€$ and between 2,500 $€$ and 3,500 $€$, respectively. More than half of participants had university studies. Almost half of respondents was responsible for fuelling the car they used and 65\% nearly always tanked in the same petrol station.

\subsection{Survey results}

Tables 4 and 5 present information on the concerns about climate change, opinions on biofuels consumption effects and energy savings, biodiesel knowledge, attitudes towards biodiesel, biodiesel use and environmental lifestyles. Drivers were very concerned about climate change, mostly believed that fossil fuel consumption impacts climate change and that energy savings should precede the use of any other energy alternative. However, they were indifferent with the statement that priority must be given to biofuels over other renewable energy source.

As far as biodiesel knowledge, respondents were offered three statements about biodiesel which they had to identify as being true or false. 
Table 3 - Sample characteristics (\%, unless stated).

\begin{tabular}{|l|l|r|}
\hline \multicolumn{1}{|c|}{ Variable definition } & \multicolumn{1}{|c|}{ Name (type) } & Value \\
\hline Socio-demographic and economic characteristics & & \\
\hline Gender & & \\
Male & FEMALE (dummy: 1=female) & 51.2 \\
Female & AGE (continuous) & 48.8 \\
Age (Average from total sample) & & 44.0 \\
Education of respondent & EDUCATION (1 to 3) & \\
Primary studies & & 12.1 \\
Secondary studies & & 30.1 \\
University degrees & & 57.8 \\
Average monthly household income & INCOME (1 to 4) & \\
Less than 1,500 $€$ & & 13.8 \\
Between 1,501 and 2,500 $€$ & HSIZE (continuous) & 31.2 \\
Between 2,501 and 3,500 $€$ & & 29.6 \\
More than 3,500 $€$ & & 25.4 \\
Household Size (Average from total sample) & & 3.2 \\
\hline How often do you fuel the car you used? & & \\
Never & ALWAYS (dummy: 1=always) & 20.4 \\
Rarely & & 16.3 \\
Sometimes & FIDELITY (dummy: 1=yes) & 41.5 \\
Often & 64.8 \\
Always & & 13.8 \\
Do you usually fuel the car in the same petrol station? & & \\
\hline
\end{tabular}

The statements were: (i) biodiesel is produced from vegetable or animal oils; (ii) biodiesel is a renewable energy; and (iii) biodiesel can be used in any diesel engine without specific modifications. Respondents answering correctly to the three questions, all-true, were considered to have an objective knowledge about biodiesel. Using this definition, less than $20 \%$ of respondents can be characterized as knowing what biodiesel is. Attitudes towards biodiesel were measured asking respondents to rate their degree of agreement with different statements related to biodiesel using a five-point scale (Table 4). Respondents highly believed that biodiesel can be produced from raw material from the region, its use reduces oil import dependence and contributes to the increase of farmers' income (with average rating 4 or higher). On the other side, they believed to a lesser extent that biodiesel may increase the price of food products and its cost of production is higher than the cost of producing conventional diesel. Therefore, in general terms we can conclude that Spanish drivers presented positives attitudes towards biodiesel. Biodiesel actual use was measured asking respondents their frequency of use of biodiesel (Table 5). Around twothird of respondents stated that they have never used biodiesel. Finally, environmental lifestyles were measured. First, participants were asked whether they belong to an environmental conservation association (Table 4). Second, they had to indicate some environmental lifestyles (Table 5). Less than $10 \%$ of respondents stated that they belong to an environmental conservation association. While $80 \%$ of respondent manifested that they often or always dispose their garbage in selected containers and try to save water, only $44 \%$ stated that often or always use environmentally friendly products.

\subsection{Willingness to pay results}

Comparing the results of these three models (MNL, RPL and RPL-corr) the RPL-corr was selected as it attained the best fit using the log-likelihood and because the assumptions of 
Table 4 - Concerns on climate change and biodiesel knowledge and attitudes.

\begin{tabular}{|l|l|c|}
\hline \multicolumn{1}{|c|}{ Variable definition } & \multicolumn{1}{|c|}{ Name (type) } & Value \\
\hline $\begin{array}{l}\text { Concerns on climate change } \\
\text { How much do you worry about the climate change? } \\
\text { (1=not at all to 5=very much) }\end{array}$ & CLIMACHANGE & 3.96 \\
\hline $\begin{array}{l}\text { Believes on biofuels consumption effects and energy savings } \\
\text { (level of agreement: 5-point increasing scale) }\end{array}$ & & \\
\hline Fossil fuel consumption has impact on the climate change & FOSSIL & 4.09 \\
\hline Energy savings should precede the use of any other energy alternatives & ENERGYSAVING & 4.04 \\
\hline Priority must be given to biofuels over other renewable energy sources & BIOFUEL & 3.49 \\
\hline Consumers'knowledge on biodiesel & & \\
\hline Objective knowledge (dummy: 1=yes) & KNOW & 19.2 \\
\hline $\begin{array}{l}\text { Consumers attitudes towards biodiesel } \\
\text { (level of agreement: 5-point increasing scale) }\end{array}$ & & \\
\hline Biodiesel can be produced from raw material from my region & REGIONAL & 4.04 \\
\hline $\begin{array}{l}\text { The cost of production of biodiesel is higher than the cost of producing } \\
\text { conventional diesel }\end{array}$ & COST & 3.46 \\
\hline Biodiesel may increase the price of food products & FOOD & 3.40 \\
\hline Biodiesel use reduces oil import dependence & DEPENDENCE & 4.02 \\
\hline Biodiesel use reduces the risk of climate change & RISKCLIMA & 3.90 \\
\hline Biodiesel use contributes the increase of farmers income & INCOMES & 4.00 \\
\hline Biodiesel use diminishes GHG emissions & GHG & 3.99 \\
\hline $\begin{array}{l}\text { Do you belong to an environmental conservation association? } \\
\text { (dummy: } 1=y e s)\end{array}$ & ENVIROASS & 9.8 \\
\hline
\end{tabular}

Table 5 - Use of biodiesel and environmental lifestyles.

\begin{tabular}{|l|c|c|c|c|c|}
\hline \multicolumn{1}{|c|}{ Questions } & Never & Rarely & Sometimes & Often & Always \\
\hline Frequency of biodiesel use & & & & & \\
\hline $\begin{array}{l}\text { Do you use biodiesel? BIOUSE (dummy: } \\
\text { 1=never) }\end{array}$ & 73.4 & 14.8 & 10.5 & 1.0 & 0.25 \\
\hline Environmental lifestyles & & & & & \\
\hline $\begin{array}{l}\text { Split waste according to recycling options } \\
\text { available GARBAGE (dummy: 1=always) }\end{array}$ & 2.8 & 2.8 & 14.6 & 27.9 & 52.0 \\
\hline $\begin{array}{l}\text { Use environmentally friendly products } \\
\text { (recycled, organic, ...) ENVIROFRIENDY } \\
\text { (dummy: } 1=\text { always) }\end{array}$ & 2.5 & 9.8 & 44.0 & 31.9 & 11.8 \\
\hline $\begin{array}{l}\text { Save water SAVEWATER (dummy: } \\
\text { 1=always) }\end{array}$ & 1.5 & 1.3 & 17.6 & 42.0 & 37.7 \\
\hline
\end{tabular}


homogenous preferences (MNL) and uncorrelated parameters were rejected. In particular, the standard deviations for the estimate parameters and the Cholesky matrix were statistically significant different from zero. Results for this final model are reported in Table 6 and used for further discussion.

The model is statistically significant with a $\chi^{2}$ of 1,221 which is higher that the critical value, suggesting that the attributes-levels were jointly significant, affecting consumers' utility. As expected, the non-random parameter (PRICE) was negative and statistically significant different from zero at the $1 \%$ of significance level. Therefore, price increments decrease the associated utility level provided by the choice of each diesel options. The rest of parameters were statistically significant explaining drivers' utility and positive. The parameters for the two types of biodiesel (BIO and BIOCERT) were positive which means that drivers got higher utility for biodiesel and certificated biodiesel than for the conventional diesel. The AVAILABILITY variable was also positive indicating that drivers attained higher utility when the diesel is available in the petrol station close to their daily route. Finally, the positive value for the parameter estimate for the EUROPE variable indicates that drivers gain utility when the diesel is produced in Europe. Looking to heterogeneity in preferences, the Wald statistics for the derived standard deviation parameters indicates that the dispersion around the mean estimate was statistically different from zero for the attributes-levels.

Of particular interest are the estimates of drivers' WTP presented in the last two columns of Table 6. Estimated WTP were positive and statistically different from zero. Drivers were willing to pay an extra price of $0.05 € / 1$ and 0.06 $€ / 1$ to use biodiesel and biodiesel with sustainable certification in relation to the conventional diesel, respectively. Moreover, availability of the biodiesel was the most valued attribute $(0.07 € / 1)$. Finally, the least valued attribute was the place of production with an average WTP of around $0.02 € / 1$ reflecting that consumers positively valued that the biodiesel is produced in Europe but to a lesser extent.

Table 6 - Results for the RPL model: parameters and WTPs.

\begin{tabular}{|c|c|c|c|c|}
\hline & Parameters & t-values & $\begin{array}{c}\text { Mean WTP } \\
\epsilon / l\end{array}$ & $t$-values \\
\hline \multicolumn{5}{|l|}{ Mean values } \\
\hline PRICE & -18.1692 & -19.70 & & \\
\hline $\mathrm{BIO}$ & 0.8744 & 6.31 & 0.048 & 6.38 \\
\hline BIOCERT & 1.1850 & 7.88 & 0.065 & 7.86 \\
\hline AVAILABILITY & 1.3031 & 8.08 & 0.072 & 7.84 \\
\hline EUROPE & 0.3056 & 2.74 & 0.017 & 2.72 \\
\hline \multicolumn{5}{|c|}{ Standard deviation for parameter distribution } \\
\hline $\mathrm{BIO}$ & 1.4780 & 9.24 & & \\
\hline BIOCERT & 1.7071 & 10.01 & & \\
\hline AVAILABILITY & 1.9969 & 9.87 & & \\
\hline EUROPE & 1.3982 & 9.96 & & \\
\hline Sample size & 7,164 & & & \\
\hline Log-likelihood & $-2,012.84$ & & & \\
\hline$\chi^{2}$ & $1,221.28$ & & & \\
\hline Pseudo $\mathrm{R}^{2}$ & 0.23 & & & \\
\hline
\end{tabular}




\subsection{Explaining heterogeneous preferences}

As reported in Table 6, consumer's utilities differed across drivers for the different attributes. To explain the nature of this heterogeneity we conducted a cluster analysis using the individual specific WTPs derived from the estimations presented in Table 6 .

The cluster analysis provides two consumer segments of similar sizes. To see whether the clusters are really different in terms of the segmentation variables (individual WTPs), we start by checking whether the two segments really differ in terms of estimated WTPs using an ANOVA Bonferroni test.

Table 7 indicates that all the estimated WTPs were statistically different between the two clusters. The mean values of these WTPs were used to name the different clusters according to drivers' preferences for diesel.

Thus, cluster 1 consisted of $56 \%$ of respondents and it was named "Biodiesel seekers", because this segment attached more value than segment 2 to the biodiesel. In the same way, cluster 2 with $44 \%$ of respondents was named "Convenience seekers" because drivers in this segment value the availability of the biodiesel in the petrol station close to their daily route more than "Biodiesel seekers". "Biodiesel seekers" were willing to pay $0.10 € / 1$ for the biodiesel with sustainable certification and $0.07 € / 1$ for the biodiesel in relation to the diesel. They valued more the biodiesel produced in Europe $(0.03 € / 1)$ than the availability of the diesel in the petrol station close to the everyday route $(0.02 € / 1$. On the contrary, "Convenience seekers" valued the availability of the biodiesel the most $(0.07 € / 1)$ and did not care about the origin of the biofuel. Their WTP for the biodiesel is the lowest $(0.02 € / 1)$.

To profile these two clusters we conducted ANOVA and chi-square tests for the two clusters and the different drivers' characteristics displayed in Tables 3, 4 and 5. The results of these tests are summarized in Table 7.

The "Biodiesel seekers" segment included more women with higher education and income levels. In addition, they were younger and shared the fuelling tasks with other drivers of the car (ALWAYS) and fuel the car always in the same petrol station (FIDELITY). "Biodiesel seekers" drivers were more concerned about climate change (CLIMATECHANGE) and they highly believed that fossil fuel consumption has impact on the climate change (FOSSIL). In the same way, they believed more than that energy savings should precede the use of any other energy alternatives (ENERGYSAVING) and that priority must be given to biofuels to other renewable energy sources (BIOFUEL). "Biodiesel seekers" were more knowledgeable on biodiesel and presented more positive attitudes because they highly rated all the attitudes statements except for the one "biodiesel may increase the price of food products" (FOOD). This can be characterized as people that believed that biodiesel use diminishes GHG emissions, its use contributes the increase of farmers' income and that is produced from raw material from my region. On the other hand, they do not see that there is a conflict between biodiesel and food security via increased food prices. Moreover, this segment has a larger experience in biodiesel use as nearly half of them stated having used biodiesel (BIOUSE), while only a minority of convenience seekers had (less than 7\%). Last, this segment also exhibited a more friendly environmental lifestyles with higher participation in environmental conservation associations and more frequent environmentally friendly behaviours (separate waste, purchase environmentally friendly products and save water).

\section{Discussion}

Drivers' preferences for biodiesel were explored using a DCE approach. Findings indicated that drivers were willing to pay an extra price of $0.05 € / 1$ and $0.06 € / 1$ to use biodiesel or biodiesel with sustainable certification, respectively. This result is in agreement with Giraldo et al. (2010) who found that consumers were willing to pay $0.05 € / 1$ more for biodiesel compared to diesel price while Kallas \& Gil (2014) stated that drivers are not willing to pay for biodiesel. Taking the average price of the diesel at the time of the survey $(1.1 € / 1)$, our results stated that drivers were willing to pay, on aver- 
Table 7 - Clusters based on diesel preferences: Profile of drivers' segments.

\begin{tabular}{|c|c|c|c|}
\hline & $\begin{array}{l}\text { Biodiesel } \\
\text { Seekers }\end{array}$ & $\begin{array}{c}\text { Convenience } \\
\text { Seekers }\end{array}$ & Sample \\
\hline Size & 224 & 176 & 400 \\
\hline \multicolumn{4}{|l|}{ Mean estimated WTPs } \\
\hline Biodiesel** & 0.07 & 0.02 & 0.05 \\
\hline Biodiesel with sustainable certification** & 0.10 & 0.02 & 0.06 \\
\hline Availability in the petrol station** & 0.02 & 0.13 & 0.07 \\
\hline Produced in Europe ${ }^{* *}$ & 0.03 & 0.00 & 0.02 \\
\hline \multicolumn{4}{|l|}{ Personal characteristics } \\
\hline Gender: FEMALE** & 54.0 & 42.0 & 48.8 \\
\hline Age: $\mathrm{AGE}^{* *}$ & 43.0 & 45.7 & 44.0 \\
\hline Household size: HSIZE** & 3.3 & 3.0 & 3.2 \\
\hline \multicolumn{4}{|l|}{ Education level: EDUCATION** } \\
\hline Primary studies & 8.5 & 16.7 & 12.1 \\
\hline Secondary studies & 24.1 & 37.9 & 30.1 \\
\hline University degree & 67.4 & 45.4 & 57.8 \\
\hline \multicolumn{4}{|l|}{ Household Net Income: INCOME ** } \\
\hline Less than $1,500 € /$ month & 8.9 & 20.1 & 13.8 \\
\hline Between 1,500 and $2,500 € /$ month & 25.5 & 38.5 & 31.2 \\
\hline Between 2,500 and $3,500 € /$ month & 30.4 & 28.7 & 29.6 \\
\hline More than $3,500 € /$ month & 35.3 & 12.7 & 25.4 \\
\hline Frequency of fuelling: ALWAYS** & 30.8 & 55.2 & 41.5 \\
\hline Fuelling in the same petrol station: FIDELITY* & 68.3 & 60.3 & 64.8 \\
\hline Climate change concern: CLIMACHANGE** & 4.05 & 3.83 & 3.96 \\
\hline \multicolumn{4}{|l|}{ Believes on biofuels consumption effects and energy savings } \\
\hline FOSSIL $* *$ & 4.16 & 3.99 & 4.09 \\
\hline ENERGYSAVINGS** & 4.12 & 3.94 & 4.04 \\
\hline BIOFUEL** & 3.71 & 3.20 & 3.49 \\
\hline Knowledge on biodiesel (KNOW)** & 24.5 & 12.6 & 19.2 \\
\hline \multicolumn{4}{|l|}{ Attitudes towards biodiesel } \\
\hline REGIONAL** & 4.17 & 3.88 & 4.04 \\
\hline $\operatorname{cosT}^{* *}$ & 3.57 & 3.31 & 3.46 \\
\hline FOOD $* *$ & 3.27 & 3.56 & 3.40 \\
\hline DEPENDENCE** & 4.12 & 3.88 & 4.02 \\
\hline RISKCLIMA** & 4.06 & 3.68 & 3.90 \\
\hline INCOMES ** & 4.18 & 3.77 & 4.00 \\
\hline $\mathrm{GHG}^{* *}$ & 4.24 & 3.68 & 3.99 \\
\hline Biodiesel use (BIOUSE) Never ** & 57.6 & 93.7 & 73.4 \\
\hline Environmental conservation association (ENVIROASS)** & 14.7 & 3.5 & 9.8 \\
\hline \multicolumn{4}{|l|}{ Environmental lifestyles } \\
\hline GARBAGE** & 61.1 & 40.2 & 52.0 \\
\hline ENVIROFRIENDLY** & 14.7 & 8.0 & 11.8 \\
\hline SAVEWATER $* *$ & 49.1 & 23.0 & 37.7 \\
\hline
\end{tabular}

$*$ and $* *$ means that clusters are statistically different at $10 \%$ and $5 \%$ level of significance, respectively. 
age, a premium of $5 \%$ for the biodiesel versus the conventional diesel. Moreover, availability of the biodiesel is important because it was the most valued attribute $(0.07 € / 1)$. This result is also in agreement with Giraldo et al. (2010) and Kallas \& Gil (2014) who stated that the proximity of the petrol station to their everyday route is the most important attribute and the WTP was $0.06 € / 1$ of diesel, in the first paper, and between $0.08 € / 1$ and $0.22 € / 1$, in the second. Then, our results indicate that consumers would need, on average, a $6 \%$ discount to tank in a petrol station, which implies a detour in the daily route. Finally, the least valued attribute was the place of production with a medium WTP of around $0.02 € / 1$. Then, drivers positively valued that the biodiesel is produced in $\mathrm{Eu}-$ rope but to a lesser extent. This last result is one of the contributions of our study because, as far as we know, no previous empirical studies had measured this attribute.

A key issue is whether this premium would overcome the additional costs of certification. Certified biodiesel had a premium over non-certified biodiesel of almost $0.02 € / 1$. While certified biodiesel seemed to be a sub-optimal solution in terms of cost comparisons with consumer WTP, we can also check whether it was a competitive mitigation option comparing the WTP in terms of price per ton of $\mathrm{CO} 2$ with the other $\mathrm{CO} 2$ prices currently being paid in the market. Diesel emits on average 2.64 kilos of CO2/1 (Ecoscore, no date) and considering the average cost of $\mathrm{CO} 2$ in the EU's Emmission Trading System (28.5 €/t at the time of writing [July 2019] and $15 € / \mathrm{t}$ at the time of the survey [2010]) the equivalent WTP for the emissions mitigated using one litre of certified biodiesel was 0.07 , and $0.04 € / 1$, respectively. Therefore, drivers' willingness to pay for certified biodiesel in terms of mitigation of $\mathrm{CO} 2$ are lower than prices prevailing at the time of the survey and in line with current ones.

The premium for biodiesel (5\%) was lower than the extra-price that drivers were willing to pay for filling diesel up in their usual petrol station (6\%). This result implies that biodiesel will only be successful if made available in a larger number of petrol stations. When consumers need to change their petrol station to tank biodiesel, the disutility associated with changing the route is higher than the additional utility attached to biodiesel. Results show that in these circumstances biodiesel could be marketed with a premium price of $5 \%$ respect to the conventional diesel.

Other relevant result is that biodiesel demand is heterogeneous and shows a clear split between two segments of drivers according to their WTP for the different attributes. "Biodiesel seekers" were more willing to pay for biodiesel and "Convenience seekers" for its availability. Both segments also differed in their valuation of the geographical origin (i.e. biodiesel produced in Europe). In particular, "Biodiesel seekers" drivers were willing to pay an extra premium for the biodiesel of European origin, while drivers in the "Convenience seekers" segment were not willing to pay for it. These findings on heterogeneity in preferences are also a new contribution of our work because the previous empirical papers did not study the possible heterogeneity in drivers' willingness to pay for biodiesel (Giraldo et al., 2010; Kallas \& Gil, 2014). The "Biodiesel seekers" corresponds with female, younger, more educated and higher income consumers. However, other factors beyond socio-demographics characterized the drivers in this segment. They were more concerned on climate change and the consequences of the use of energy on this change, were more knowledgeable on biodiesel and they had more positive attitudes towards biodiesel. In particular, these drivers highly considered that biodiesel can be produced in the region and has higher production costs than conventional diesel. They also believed that biodiesel consumption may reduce the oil import dependence, the risk of climate change, help to increase farms incomes and diminishes GHG emissions. These drivers believed to a lesser extent that there is a fuel/food tradeoff as they considered that the use of biodiesel does not necessarily increase the price of food products. One can conclude that drivers more willing to pay for the biodiesel are more knowledgeable on biodiesel, present more positive attitudes towards biodiesel and more friendly environmental lifestyles. 
Thus, public policies could promote biodiesel use by increasing social awareness and knowledge about benefits of biodiesel using information campaigns. A society well informed about the positive consequences for the agriculture and the environment of using biodiesel would increase its WTP. In particular, this information should be directed not only to the adult population but also to children and youth in schools for a more environmentally concerned next generation. Results from this paper are country specific and future research should be done in other geographical areas, moreover as certified 1 st generation biofuels are expected to have a reduced role in decarbonisation strategies towards 2050, similar studies for next generation biofuels should be conducted to see whether drivers exhibit the same preferences for these new technologies.

\section{Acknowledgements}

This research has been funded by Obra Social "La Caixa" and Gobierno de Aragón under the Project "Sustainable alternatives for energy power in Aragon: a view from the demand side" ("Alternativas sostenibles para la generación de energía en Aragón: una visión desde la demanda"). We would also like to thank the reviewers for their comments that have significantly improved the initial version of the work.

\section{References}

Aguilar F.X., Cai Z., Mohebalian P., Thompson W., 2015. Exploring the drivers' side of the "blend wall": U.S. consumer preferences for ethanol blend fuels. Energy Economics, 49: 217-226, https://doi.org/10.1016/j.eneco.2015.01.019.

Banse M., van Meijl H., Tabeau A., Woltjer G., Hellmann F., Verburg P.H., 2011. Impact of EU biofuel policies on world agricultural production and land use. Biomass and Bioenergy, 35, 2385-2390, https://doi.org/10.1016/j.biombioe.2010.09.001.

Bateman I.J., Carson R.T., Day B., Hanemann M., Hanley N., Hett T., Jones-Lee M., Loomes G., Maourato S., Özdemiroglu E., Pearce D., Sugden R., Swason J., 2002. Economic Valuation with Stated Preference Techniques: A Manual. Cheltenham: Edward Elgar.
Britz W., Hertel T.W., 2011. Impacts of EU biofuels directives on global markets and EU environmental quality: An integrated PE, global CGE analysis. Agriculture, Ecosystems and Environment, 142: 102-109, https://doi.org/10.1016/j. agee.2009.11.003.

Comisión Nacional de los Mercados y la Competencia (CNMC), 2019. Estadística de Biocarburantes. https://www.cnmc.es/estadistica/estadistica-de-biocarburantes.

Ecoscore, no date. How to calculate the CO2 emission from the fuel consumption?. http://ecoscore. be/en/info/ecoscore/co2.

European Commission (EC), 2009. Directive 2009/28/EC of the European Parliament and of the Council of 23 April 2009 on the promotion of the use of energy from renewable sources and amending and subsequently repealing Directives 2001/77/EC and 2003/30/EC. https:/eur-lex. europa.eu/LexUriServ/LexUriServ.do?uri=O$\mathrm{J}: \mathrm{L}: 2009: 140: 0016: 0062: \mathrm{en}: \mathrm{PDF}$

European Commission (EC), 2016. EU reference scenario 2016 energy, transport and GHG emissions trends to 2050. Luxembourg: Publication Office of the European Communities.

European Environment Agency (EEA), 2012. Greenhouse gas emission trends and projections in Europe. Tracking Progress towards Kyoto and 2020 Targets, EEA Report No 6/2012. Luxembourg: Publications Office of the European Union. https://www.eea.europa.eu//publications/ghgtrends-and-projections-2012.

European Environment Agency (EEA), 2018a. Recent trends and projections in EU greenhouse gas emissions, EEA Briefing No 12/2018. https:// www.eea.europa.eu/publications/recent-trendsand-projections-in.

European Environment Agency (EEA), 2018b. Greenhouse gas emissions from transport. https:// www.eea.europa.eu/data-and-maps/indicators/ transport-emissions-of-greenhouse-gases/transport-emissions-of-greenhouse-gases- 11 .

European Union (EU), 2015. Directive 2015/1513 of the European Parliament and of the Council of 9 September 2015 amending Directive 98/70/EC relating to the quality of petrol and diesel fuels and amending Directive 2009/28/EC on the promotion of the use of energy from renewable sources. https://eur-lex.europa.eu/legal-content/EN/ TXT/?uri=CELEX\%3A32015L1513.

European Union (EU), 2018. Directive 2018/2001 of the European Parliament and of the Council of 11 December 2018 on the promotion of the use of en- 
ergy from renewable sources. http://data.europa. eu/eli/dir/2018/2001/oj.

EurObserv'ER, 2018. Biofuels barometer. https:// www.eurobserv-er.org/category/all-biofuels-barometers/.

Farm Europe, 2016. Producing fuel and feeds. A matter of security and sustainability for Europe. Accessible at: https://www.farm-europe.eu/travaux/ poducing-fuel-and-feeds-a-matter-of-security-and-sustainability-for-europe/.

Giraldo L., Gracia A., Do Amaral E., 2010. Willingness to pay for biodiesel in Spain: a pilot study for diesel consumers. Spanish Journal of Agricultural Research, 18(4), 887-894, https://doi.org/10.5424/ sjar/2010084-1382.

Hair J.F., Anderson R.E., Tathan R.L., Black W.C., 1998. Multivariate Data Analysis. Upper Saddle River, New Jersey: Prentice-Hall International.

Jensen K.L., Clark C.D., English B.C., Menard R.J., Skahan D.K., Marra A.C., 2010. Willingness to pay for E85 from corn, switchgrass, and wood residues. Energy Econ., 32(6): 1253-1262. https://doi. org/10.1016/j.eneco.2010.06.002.

Kallas Z., Gil J.M., 2014. Consumers' preferences towards biodiesel in the Spanish transport sector: a case study in Catalonia. Paper presented at the 2014 International Congress, European Association of Agricultural Economists, Ljubljana, Slovenia, August 26-29 (No. 182801). https://ageconsearch. umn.edu/record/182801? $1 \mathrm{n}=\mathrm{en}$.

Lancaster K., 1966. A new approach to consumer theory. Journal of Political Economy, 74(2): 132157.

Lanzini P., Testa F., Iraldo F., 2016. Factors affecting drivers' willingness to pay for biofuels: the case of Italy. Journal of Cleaner Production, 4(112): 2684-2692, http://dx.doi.org/10.1016/j.jclepro. 2015.10.080.

McFadden D., 1974. Conditional logit analysis of qualitative choice behavior. In: Zarembka P. (ed.), Frontiers in Econometrics. New York: Academic Press, pp. 105-142.

Niggol Seo S., 2017. The Behavioral Economics of Climate Change. New York: Academic Press.

Nordhaus W., 2010. Economic aspects of global warming in a post-Copenhagen environment. Proceedings of the National Academy of Sciences, 107 (26): 11721.

Padella M., Finco A., Tyner W.E., 2012. Impacts of Biofuels Policies in the EU. Economics of Energy \& Environmental Policy, 1(3), 87-104, https:// www.jstor.org/stable/e26189423.

Pancini H., Assunçao L., 2011. Sustainable biofuels in the EU: the costs of certification and impacts on new producers. Biofuels, 2(6): 595-598, https://doi. org/10.4155/bfs.11.138.

Petrolia D.R., Bhattacharjee S., Hudson D., Herndon C.W., 2010. Do Americans want ethanol? A comparative contingent-valuation study of willingness to pay for E-10 and E-85. Energy Econ., 32(1): 121128, https://doi.org/10.1016/j.eneco.2009.08.004.

Savvanidou E., Zervas E., Tsagarakis K.P., 2010. Public acceptance of biofuels. Energy Policy, 38(7): 34823488, https://doi.org/10.1016/j.enpol.2010.02.021.

Scarangelli M.A., Giannoccaro G., Prosperi M., Lopolito A., 2017. Are farmers willing to pay for bio-plastic products? The case of mulching films from urban waste. New Medit, 16(39), 56-63.

Scarlat N., Dallemand J.F., 2011. Recent developments of biofuels/bioenergy sustainability certification: A global overview. Energy Policy, 39(3) 1630 1646, https://doi.org/10.1016/j.enpol.2010.12.039.

Scarpa R., Campbell D., Hutchinson G., 2007. Benefit estimates for landscape improvements: sequential Bayesian design and respondents' rationality in a choice experiment. Land Economics, 83: 617-634, https://doi.org/10.3368/le.83.4.617.

Scarpa R., Del Giudice T., 2004. Market segmentation via mixed logit: extra-virgin olive oil in urban Italy. Journal of Agricultural and Food Industrial Organization, 2(1), https://doi.org/10.2202/15420485.1080 .

Shin J., Hwang W.S., 2017. Consumer preference and willingness to pay for a renewable fuel standard (RFS) policy: Focusing on ex-ante market analysis and segmentation. Energy Policy, 106: 32-40, https://doi.org/10.1016/j.enpol.2017.03.042.

Sivashankar P., Weerahewa J., Pushpakumara G., Galagedara L., 2016. An estimation of the willingness to pay for biodiesel: a pilot study of diesel consumers. Bio-based and Applied Economics, 5(1): 27-45, https://doi.org/10.13128/BAE-15283.

Solomon B.D., Johnson N.H., 2009. Valuing climate protection through willingness to pay for biomass ethanol. Ecol. Econ., 68(7): 2137-2144, https://doi. org/10.1016/j.ecolecon.2009.02.010.

Stern N., 2007. The economics of climate change: The Stern review. Cambridge, UK: Cambridge University Press.

Street D., Burgess L., 2007. The construction of optimal stated choice experiments. Hoboken: John Wiley \& Sons Inc.

Tagliapietra S., Zachmann G., Edenhofer O., Glachant J.M., Linares P., Loeschel A., 2019. The European Union energy transition: Key priorities for the next five years. Energy Policy, 132: 950-954, https://doi. org/10.1016/j.enpol.2019.06.060. 
Tol R.S.J., 2018. The Economic Impacts of Climate Change. Review of Environmental Economics and Policy, 12 (1): 4-25, https://doi.org/10.1093/reep/ rex027.

Train K., 2003. Discrete choice methods with simulation. Cambridge, UK: Cambridge University Press. World Bank, 2010. Economics of adaptation to climate change - Synthesis report (English). Washington, DC: The World Bank. http://documents. worldbank.org/curated/en/646291468171244256/ Economics-of-adaptation-to-climate-change-Synthesis-report.
Zemo K.H., Termansen M., 2018. Farmers' willingness to participate in collective biogas investment: A discrete choice experiment study. Resource and Energy Economics, 52: 87-101, https:doi. org/10.1016/j.reseneeco.2017.12.001.

Zhang W., Yu E.A., Rozelle S., Yang J., Msangi S., 2013. The impact of biofuel growth on agriculture: Why is the range of estimates so wide?. Food Policy, 38, 227-239, https://doi.org/10.1016/j.foodpol.2012.12.002.

\section{Annex}

\section{Population in Spain and in Zaragoza}

Table A1 - Population by sex and age in Spain and in Zaragoza (\%).

\begin{tabular}{|l|r|r|c|c|c|c|c|c|}
\hline \multicolumn{2}{|c|}{} & \multicolumn{2}{|c|}{ Gender } & \multicolumn{5}{c|}{ Age } \\
\hline & Total & Female & Male & $0-19$ & $20-34$ & $35-54$ & $55-64$ & $\begin{array}{c}\text { More } \\
\text { than 64 }\end{array}$ \\
\hline Spain & $46,148,605$ & 50.99 & 49.01 & 19.88 & 20.80 & 31.10 & 11.05 & 17.14 \\
\hline Town & 952,383 & 50.90 & 49.10 & 18.46 & 19.63 & 30.83 & 11.64 & 19.42 \\
\hline
\end{tabular}

Source: Spanish Census of Population, 2011 (www.ine.es). 